GRIPS Discussion Paper 16-01

\title{
Rising Wages, Yuan Appreciation and China's Processing Exports
}

\author{
Yuqing Xing
}

April 2016

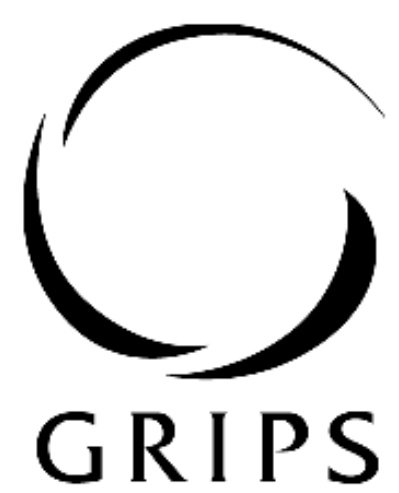

National Graduate INSTITUTE FOR POLICY STUDIES

National Graduate Institute for Policy Studies

7-22-1 Roppongi, Minato-ku,

Tokyo, Japan 106-8677 


\title{
Rising Wages, Yuan Appreciation and China's Processing Exports
}

\author{
Yuqing Xing \\ National Graduate Institute for Policy Studies \\ Tokyo, Japan \\ Email: yuqing_xing@grips.ac.jp
}

April, 2016

\begin{abstract}
This study investigates the impacts of rising wages and the appreciation of the yuan on the structure of China's exports. China's exports are classified here as ordinary exports (OE) and two distinctive groups of processing exports, pure assembly exports (PAE) and mixed assembly exports (MAE). The data analyzed here are derived from panel data covering China's bilateral PAE and MAE trade with more than 100 trading partners from 1993 to 2013. Estimates of fixed effect models show that wage increases and the appreciation of the yuan reduced the proportion of assembly exports in China's bilateral exports. Specifically, for a $1 \%$ increase in Chinese manufacturing wages, the share of PAE in China's bilateral exports is expected to fall 1.6 percentage points and that of MAE to decrease by 1.1 percentage points; a $1 \%$ nominal appreciation of the yuan against the US dollar would be expected to lower PAE and MAE trade volume by 2.4 and 2.1 percentage points, respectively. The empirical results imply that rising wages and cumulative appreciation of the yuan have eroded China's comparative advantage in the assembly of products for international markets, resulting in substantial contraction of processing exports. The analysis provides a supply-side explanation for the fall of China's export growth.
\end{abstract}

Key Words: China, Wage, Exchange Rates, processing trade

JEL: F1 


\section{Introduction}

Exports have for some time been one of the critical engines driving the rapid growth of the Chinese economy. It is estimated that, on average, exports accounted for one third of China's annual GDP growth between 2002 and 2007 (Xing and Manisha, 2013). The massive expansion of exports in recent decades has transformed China into the largest exporting nation in the world. After the global financial crisis of 2008, however, the engine of exports lost steam and the growth of exports plummeted to $-2.8 \%$ in 2015 from $20 \%$ five years earlier. This suggests that the era of double-digit growth is over.

To a certain extent, weakened demand in the US, Japan and the European Union, major destinations for China's exports, substantially undermined growth momentum. The slowing of growth might also have been a result of the government's so-called "rebalancing strategy," involving a shift from exportoriented to domestic consumption-oriented growth. The scale of exports, more than $\$ 2$ trillion annually, could also have reduced the pace of export expansion. On the other hand, the deceleration of exports indicates that the impact of supply factors such as yuan appreciation and persistent wage increases is worthy of investigation.

Since July 2005 the yuan value of the US dollar has decreased from 8.3 to 6.3 , a $35 \%$ nominal appreciation of the yuan. Given the disparity between inflation rates in the US and China, the real appreciation of the yuan could be even higher. Moreover, wages in China have risen steadily in recent years. The average annual wage of Chinese workers has risen more than $13 \%$ every year since 2000 and surged to 54,000 yuan (around US $\$ 8,000$ ) in 2014. If the growth of Chinese worker productivity failed to compensate for the increase in production costs due to cumulative wage increases and currency appreciation, profit margins and export competitiveness would be undermined, hurting the growth of exports.

Processing exports, accounting for a large share of China's exports, are heavily dependent on the input of cheap labor and have a razor-thin profit margin. Wage increases and the appreciation of the yuan have clearly eroded the profit margins of processing exports, thus constraining the expansion of processing exports and even driving some firms specializing in processing exports to exit or relocate to 
third countries. The widespread bankruptcies of manufacturing firms in Dong Guan, a Chinese city near Hong Kong where many firms engaging in assembly exports have clustered, is a typical example. Some foreign companies which had been using China as an export platform began to relocate their production facilities to the home country or to third countries. Results of a JETRO survey reveal that $13.5 \%$ of Japanese affiliated electronic machinery firms planned to either downsize operations in China or retreat altogether (JETRO, 2014). The exit of both domestic and foreign firms from processing exports unambiguously undercut China's export capacity, leading to the deceleration of export expansion. The proportion of processing exports in China's total exports dropped to $39 \%$ in 2013 from a peak of $55 \%$ in 2004, a significant contraction of processing exports, which had powered the double-digit export growth following China's official entry into the WTO.

The impact of wage increases and currency appreciation on exports is a classic research topic. Numerous studies have investigated the effect of exchange rates on China's exports, concentrating mainly on estimating the exchange rate elasticity of exports. Gacia-Herrero and Koivu (2009) used a co-integration technique to estimate the long-run elasticities of China's processing exports and imports to real exchange rates. Chung, Chinn and Fujii (2009) analyzed a similar issue over the relatively long period from 1980 to 2006. Azizi and Li (2007) emphasized dynamic changes in export elasticity. Thorbecke and Smith (2010) simulated the impact of joint appreciation of the currencies of all East Asian economies on China's processing exports. Xing (2012) argued that the processing imports of China represent external demand and should fall, not increase, as the yuan appreciates, and demonstrated how processing imports would decrease $5.0 \%$ for a $10 \%$ real appreciation of the yuan against the US dollar.

All of the studies mentioned above implicitly assume that the underlying impact of the yuan's appreciation is experienced through price mechanisms. In other words, when the yuan appreciates against foreign currencies, the prices of Chinese exports are expected to rise. This increase in prices reduces the demand by foreign consumers and thus causes a fall of exports. However, about $80 \%$ of Chinese exports are invoiced in the US dollar, so there is no automatic exchange 
rate pass-through mechanism for these exports. In other words, without raising dollar-denominated prices, Chinese exporters simply cannot pass the cost of the yuan's appreciation on to foreign buyers. In addition, most Chinese exporters, in particular those specializing in processing exports, have no pricing power. It is highly unlikely that Chinese manufacturers of processing exports would be able to renegotiate processing fees and pass the cost of currency appreciation on to foreign buyers or contractors.

To cope with wage increases and currency appreciation, firms usually adjust their operating strategies. Domestic firms may opt to exit the assembly business; multinational companies using China as an export platform may relocate production capacity to third countries; and foreign companies may outsource labor-intensive tasks to countries where wages are lower than in China. These adjustments not only reduce export capacity but also give rise to changes in export structure. Nevertheless, the impacts of such operational adjustments on export structure are irrelevant to, and cannot be captured by, exchange rate elasticity. Estimations of elasticity cannot determine to what extent wage increases and currency appreciation have affected export structure, nor can they measure the consequences of firms' exit from the processing export sector.

This paper investigates the impact of currency appreciation and wage increases on the structure rather than the volume of China's exports. Export structure is defined here in terms of production methods, not commodity categories. Specifically, we divide exports into ordinary exports (OE), pure assembly exports (PAE) and mixed assembly exports (MAE). OE refers to exports which generally do not involve imported parts and components, and whose value added is $100 \%$ domestically produced; PAE refers to processing exports created with supplied materials as defined by Chinese Customs; and MAE are processing exports created with imported materials. The sum of PAE and MAE is equal to the total processing exports reported in China's foreign trade statistics. The paper reports the analysis of data on China's bilateral assembly exports with more than 100 trading partners during the period 1993-2013. This is the first study to investigate the impact of wages and exchange rates on China's export structure, defined in terms of production methods. 


\section{Processing exports and the evolution of China's export structure}

Processing exports have been a major export modality in China, contributing significantly to overall growth, e.g., from $\$ 73.7$ billion to $\$ 860$ billion between 1995 and 2013. During the high-growth period 1995-2007, processing exports accounted for more than $50 \%$ of China's total exports. At the peak, the share was $57 \%$ (see figure 1). It is estimated that more than $80 \%$ of China's high-tech exports are processing exports, which makes China the top high-tech exporting nation in the world (Xing, 2014).

Assembling parts and components into finished products is a necessary but low value added segment of global value chains (GVCs). Aside from China's comparative advantage in labor endowment, the rapid expansion of China's processing exports is mainly attributed to Chinese firms' active participation in value chains of global manufacturing. Since 1990, the influx of foreign direct investment and the outsourcing activities of multinational enterprises have integrated Chinese firms into GVCs and transformed China into the global center for assembly of manufactured products. GVCs have functioned as a vehicle for the entry of China's processing exports into international markets. All processing exports are distributed via networks established by the lead firms of value chains, which greatly enhances market access for China's exports. In addition, processing exports usually bear internationally recognized brands owned by multinational enterprises and preferred by foreign consumers, in particular consumers in developed countries. To a large extent, the spillover effects of GVCs in terms of brands, technology innovations and distribution networks have strengthened the international competitiveness of China's processing exports and greatly facilitated China's global expansion (Xing, 2016).

The dominance of processing exports began to decline in 2006, one year after China reformed its exchange rate regime and let the yuan appreciate. The share of processing exports dropped below $50 \%$ for the first time in 2008 and continued to fall, reaching $39 \%$ in 2013 . While both PAE and MAE experienced decreased shares of total exports, PAE contracted more in both relative and absolute terms. The growth of PAE turned negative in 2008. By 2013 the yearly volume of PAE had decreased to US $\$ 92.5$ billion, about $20 \%$ less than the peak of $\$ 116$ billion, 
and the share of PAE in total exports shrank to a mere $4.2 \%$. This significant contraction of PAE suggests that many firms had exited the pure assembly sector. PAE is more vulnerable than $\mathrm{OE}$ and MAE to wage increases and the appreciation of the yuan. PAE products are made exclusively with imported parts and components and require only low skilled labor services from Chinese firms. PAE processing fees, which are invoiced in the US dollar, are the only source of revenue for those firms. Wage increases and the appreciation of the yuan automatically squeeze PAE profit margins, resulting in an exodus of both domestic and foreign firms from pure assembly exports, the lowest value added segment of GVCs.

\section{Figure 1. The Structure of China's Exports, by Production Type}

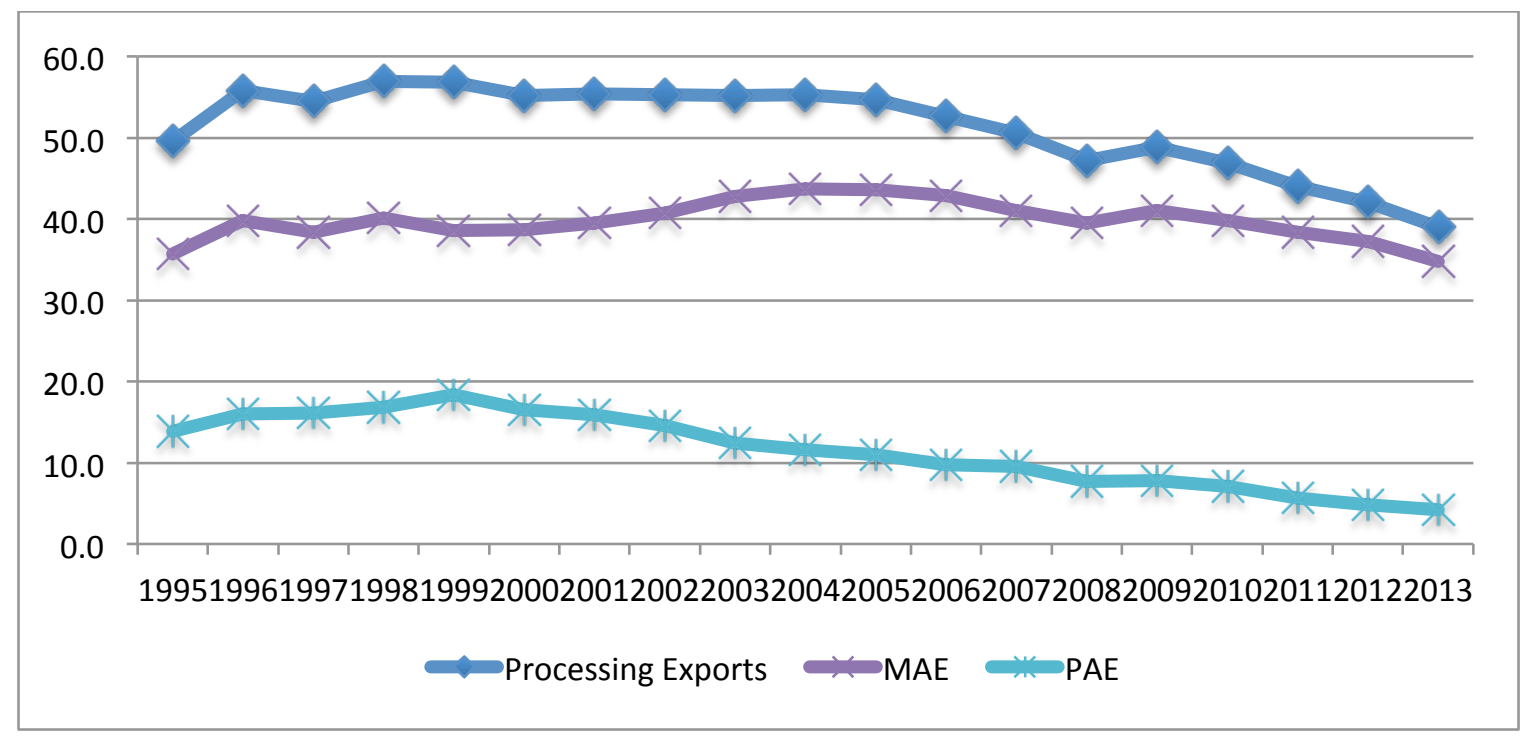

Source: the author's calculation based on data from China Customs Office.

The scale of MAE is much larger than that of PAE. In recent years, MAE has accounted for 70 to $90 \%$ of processing exports, in 2013 approximately $\$ 768$ billion, about $34 \%$ of China's total exports. MAE volume has experienced a long period of continuous growth, but the pace of that growth has slowed considerably in recent years. For instance, in 2012 and 2013, MAE grew only 5\% and $0.6 \%$, respectively, and the total exports share of MAE dropped steadily from a peak of $43.7 \%$ in 2004 . The decrease in MAE growth cannot be attributed to weakened external demand alone, because in the same years, ordinary exports grew by $11.6 \%$ and $13.7 \%$, respectively. 
In general, processing exports have several advantages over ordinary exports in international markets. They are distributed by global retail networks of multinational companies and sold under globally recognized brands. If weakened external demand results in slowed growth, ordinary exports can be expected to suffer more than MAE. Therefore, factors affecting MAE supply capacity, such as wages and exchange rates, should be taken into consideration in analysis of the decline of MAE and of processing exports as a whole.

MAE are typically manufactured using both imported and domestically made parts and components. MAE manufacturers have more leverage than PAE manufacturers to absorb the burden of wage increases and currency appreciation. They may be able to pass the burden on to domestic suppliers, or replace expensive foreign-made parts with cheaper domestic ones. Therefore, despite significant wage increases and the appreciation of the yuan, MAE still accounts for about one third of China's total exports.

\section{Figure 2. The Share of Processing Exports in China's Bilateral Exports (\%)}

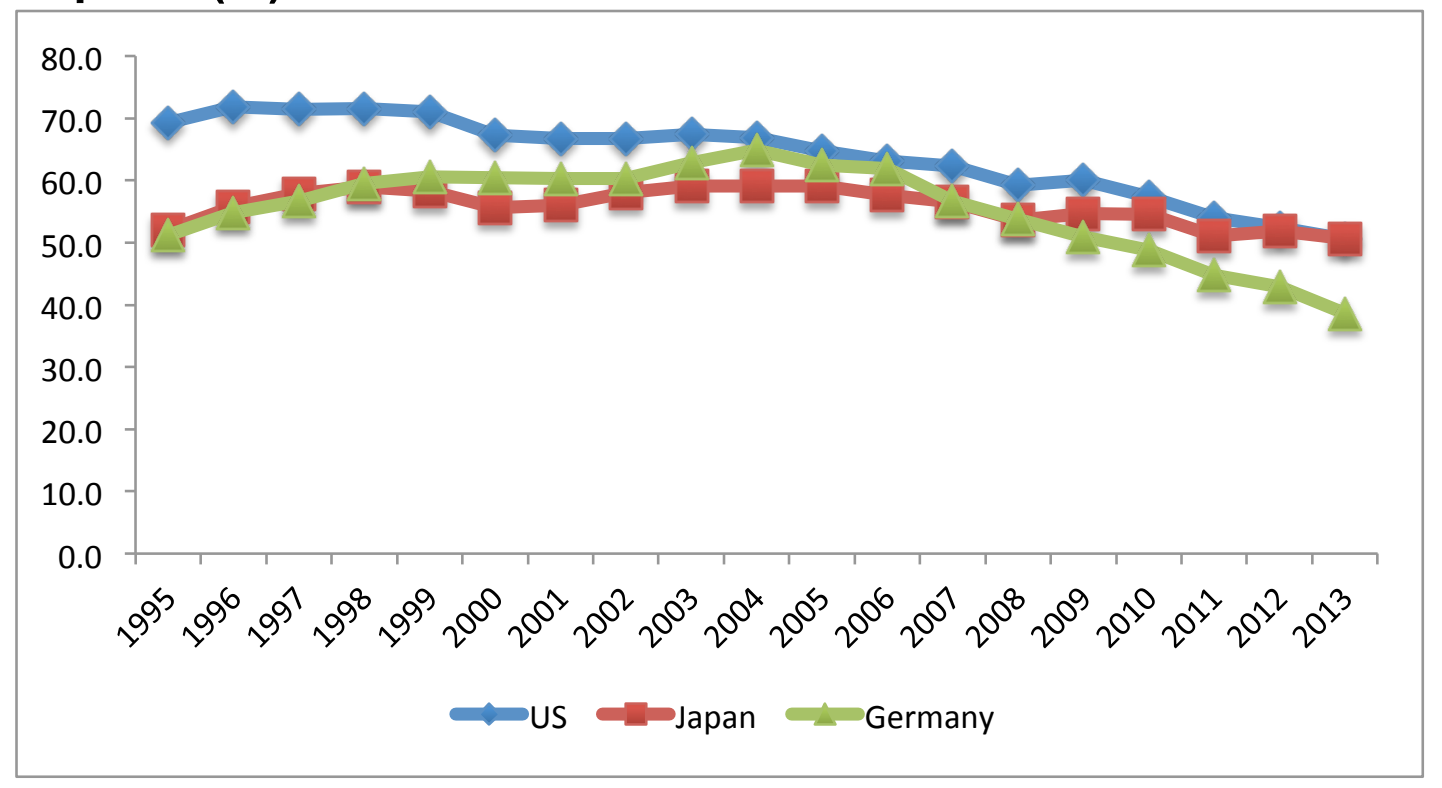

Source: the author's calculation.

The downward trend of processing exports can also be observed in China's bilateral trade, in particular its trade with high-income countries. An examination of the structure of China's exports to individual trading partners reveals a similar trend, in particularly for partners in high-income countries. Figure 2 shows the 
trends in processing exports from China to the US, Japan and Germany. From 1995-1999, about $70 \%$ of China's exports to the US were processing exports; from 2000-2009, processing exports remained dominant but their share of total exports decreased to $60 \%$. By 2013, the share of processing exports had shrunk to $51 \%$. In the case of China's exports to Japan, processing exports accounted for $52 \%$ in 1995 , gradually rose to $59.2 \%$ in 2004 , and then decreased to $50.6 \%$ in 2013. Germany has for some time been the largest European destination for China's processing exports. Processing exports accounted for $51.2 \%$ of China's exports to Germany in 1995 , reached a peak of $64.8 \%$ in 2004 , and then fell gradually to $38.6 \%$ in 2013 .

\section{Wages, currency appreciation and the exit of firms from assembly exports}

In this section, we provide a simple theoretical explanation for the effect of wages and exchange rates on the operational strategies of firms specializing in processing exports. Assume that there are two firms, one domestic and one foreign, involved in processing exports. The domestic firm, assembling imported parts to produce finished products for export, has reservation markup $\propto$ per unit of assembled exports. If the gross per unit profit margin of assembled exports is less than the markup, i.e. $\left(\mathrm{pe}-w_{c}\right)<\propto$, where $w_{c}$ denotes the Chinese yuan wage for the labor required to produce one unit of assembled exports; $p$ represents the unit assembly fee in US dollars; and e is the nominal exchange rate (the price of the dollar in terms of the yuan), then the firm will exit the assembly business. For a given assembly fee $p$, an increase in $w_{c}$ or a decrease in e (yuan appreciation) reduces the profit margin ( $\mathrm{pe}-w_{c}$ ). The profit margin will continue to decrease as wages rise and/or the yuan appreciates. Eventually the tipping point $\left(\mathrm{pe}-w_{c}\right)=\propto$ is reached and the domestic firm exits the assembly business. Before the profit margin falls to the level of the reservation markup $\propto$, it is highly likely that the firm will stop expanding its assembly business, thus reducing the growth of processing exports and giving rise to changes in the composition of exports.

A foreign firm assembling exports has the option of conducting that business in another country, so it follows a different exit decision rule: if $\frac{w_{c}}{e}$ - Chinese workers' 
wages in US dollars is higher than wages $w_{j}$ in alternative foreign country j, i.e. if $w_{c} / \mathrm{e}>\mathrm{w}_{\mathrm{j}}$, the foreign firm will leave China and outsource its assembly work (relocate assembly capacity) to country j. An increase in $w_{c}$ or a decrease in e raises Chinese workers' dollar equivalent wages. Once China's wages exceed those of country $\mathrm{j}$, the foreign firm exits the assembly of exports in China and relocates its production facility to country j. As China's labor cost advantage diminishes, because of either wage increases or the appreciation of the yuan or both, the foreign firm will eventually stop investing in new production facilities. This analysis implies that wage increases and local currency appreciation are inversely related to the profit margins of processing exports. If wage increases and local currency appreciation persist, they will eventually drive assembly firms to exit the business or relocate to other countries.

Figure 3. Monthly Salaries of Employees in Japanese Affiliates in Selected Asian Cities (US\$)

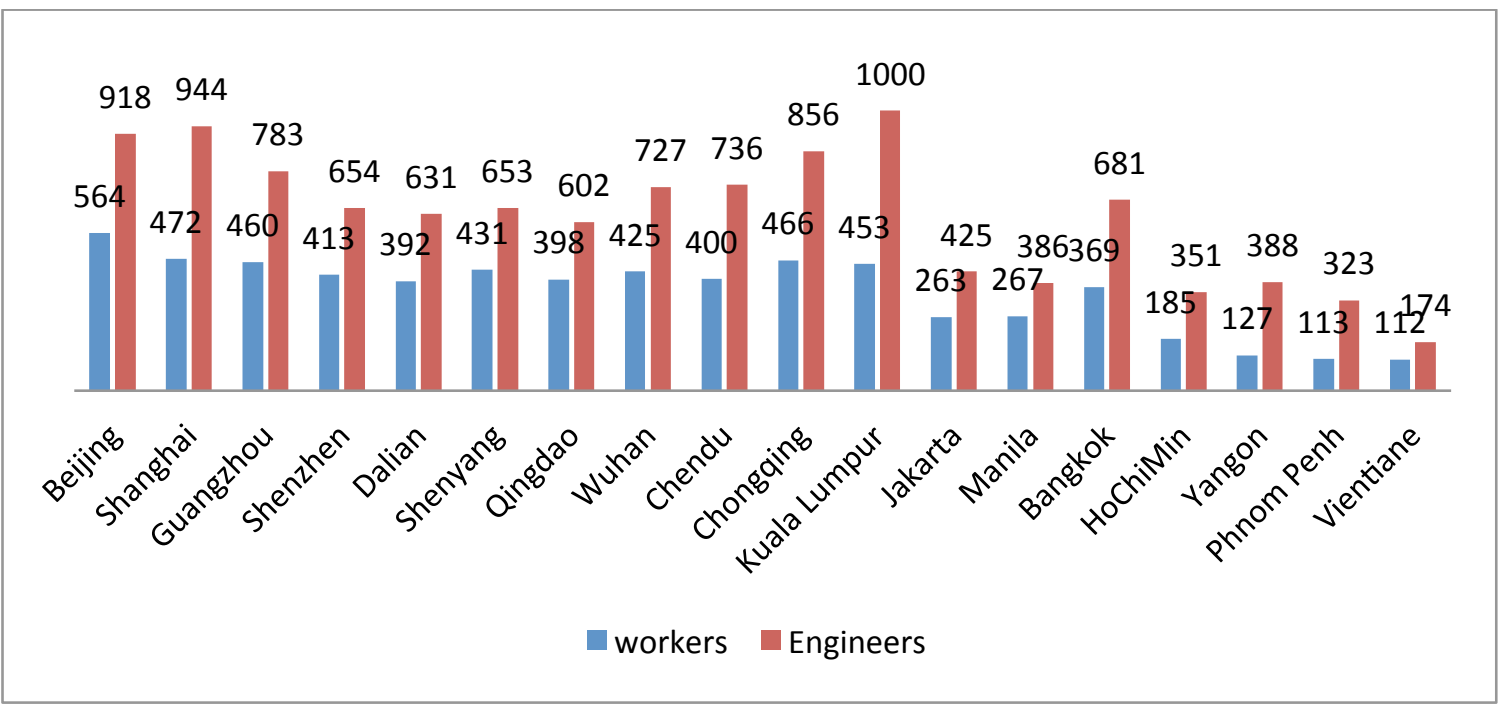

Source: JETRO (2015)

The wages of Chinese workers have exceeded those of workers in many emerging countries competing with China for the assembly tasks of GVCs. According to a 2015 JETRO survey on investment costs of Japanese affiliated firms in Asia, the average monthly salary of workers in Japanese affiliated companies in Beijing was $\$ 564$, the highest among the eight Chinese cities surveyed; that in Dalian the lowest, at $\$ 392$. However, Dalian's salary was $7.8 \%$ higher than that in Bangkok, $49 \%$ higher than in Jakarta, 51\% higher than in 
Manila and $115 \%$ higher than in Ho Chi Minh City. Local engineers hired by Japanese companies in Shanghai received an average monthly salary of $\$ 944$, the highest among the Chinese cities surveyed, while the average monthly salary of local engineers hired by Japanese companies in Qingdao was $\$ 602$, the lowest in the group. On the other hand, the average engineer's salary in Qingdao was $43 \%$ higher than that in Jakarta, $56 \%$ higher than in Manila and $71 \%$ higher than in Ho Chi Minh City (figure 3).

Figure 4. The Distribution of Japanese FDI in Asia

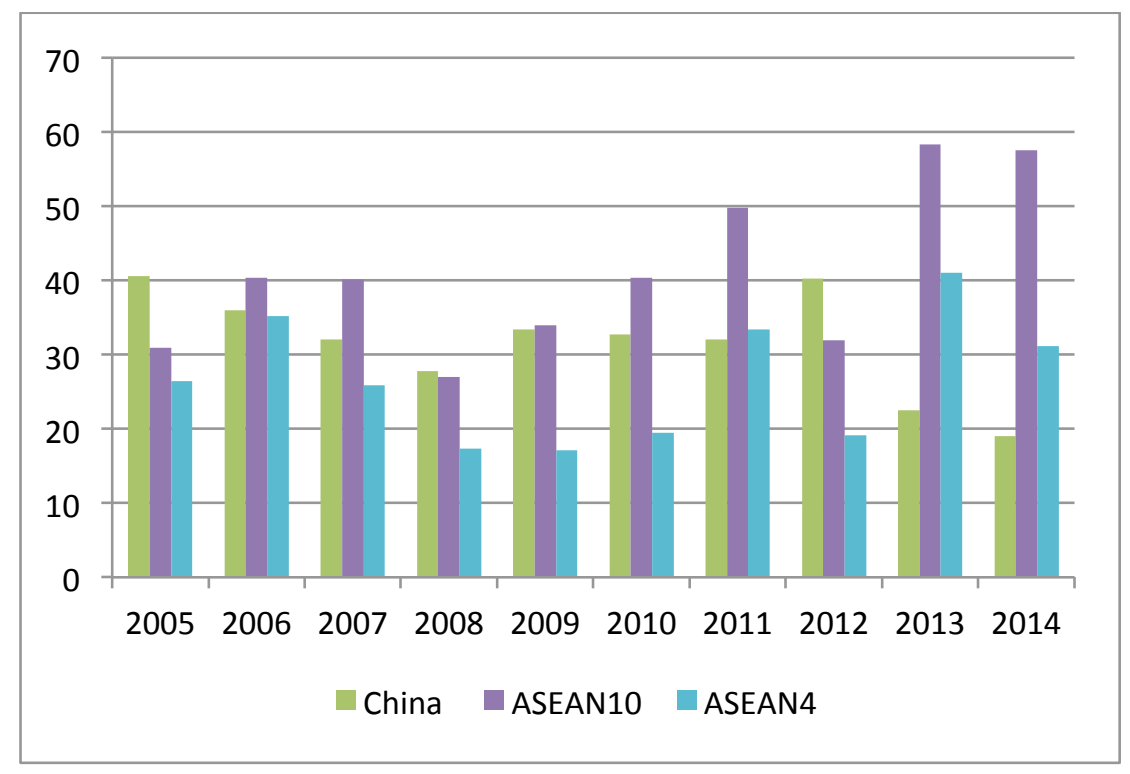

\section{Source: JETRO}

The results of the survey indicate that, compared with South East Asian countries, which have recently emerged as the top Asian destination for Japanese FDI, in terms of labor costs China has lost its competitiveness in attracting Japanese investment. Japan was the second largest source of FDI in China, but because of wage increases and the appreciation of the yuan, Japanese multinational companies no longer consider China as the top choice for the manufacture of products destined for the world market. Japanese direct investment in China fell by $33 \%$ in 2013 and $26 \%$ in 2014 , to $\$ 6.7$ billion, less than half the 2012 peak. In 2014 ASEAN countries replaced China as the largest host of Japanese FDI in Asia, receiving approximately $60 \%$ of Japanese FDI; in the same period China's share shrank from $40 \%$ in 2012 to $19 \%$ in 2014 (see figure 4). A few Japanese companies retreated from China. Japanese electronics maker Panasonic 
announced that it would move $50 \%$ of its air purifier production from China back to Japan (Kyodo News, 2015). Citizen Holdings, a well-known Japanese watch maker, closed its watch parts factory in Guanzhou in February 2015 (Nikkei, 2015). To cope with rising labor costs, Foxconn, which exports about $\$ 80$ billion in information communication technology products from China annually (Sun and Grimes, 2015), recently announced a plan to invest $\$ 5$ billion on the construction of an assembly factory in India.

\section{Empirical Analysis}

In our empirical analysis of the impacts of wage increases and currency appreciation on the structure of China's exports, we used the standard gravity model, defining China's exports $E X_{i t}$ to country $i$ as

$$
E X_{i t}=\lambda \frac{G D P_{c t} G D P_{i t}}{d_{c i}}
$$

and China's processing exports $P E X_{i t}$ to country $i$ as

$$
P E X_{i t}=\gamma \frac{G D P_{c t} G D P_{i t}}{d_{c i}} f(z)
$$

where $G D P_{c t}$ denotes China's GDP, $G D P_{i t}$ the GDP of country $i$, and $d_{c i}$ the distance between China and country $i . \lambda$ and $\gamma$ are constants. $f(z)$ is a function measuring specific characteristics of processing exports. Then the share of processing exports in China's exports to country $i$ can be expressed as

$P_{i t}=\frac{P E X_{i t}}{E X_{i t}}=\delta f(z)$

To evaluate equation (3), i.e. to determine the share of processing exports in China's bilateral exports, we apply the model

$$
\ln \left(P_{i t}\right)=\alpha+\beta_{1} \ln \left(Y_{i t}\right)+\beta_{2} \ln \left(W_{c t}\right)+\beta_{3} \ln \left(E X_{\$ t}\right)+\beta_{4} E A D+\beta_{5} E p o t+\varepsilon_{i t}
$$

defines as follows. 
The first independent variable $Y_{i t}$ denotes the real per capita GDP of country $i$. As argued above, processing exports mainly target the markets of high-income countries, where consumer preference for brand and high-tech products is much stronger than in low-income countries. Xing (2016) shows that among China's trading partners there is a significant log-linear relation between the share of processing exports and GDP per capita. $W_{C t}$ represents the wage of Chinese workers. $E A D$ is a dummy variable equal to one when the trading partners are from East Asian countries. Chinese firms are deeply involved in regional value chains established by Japanese and Korean multinational enterprises. China's processing exports show significant regional bias towards East Asia. A substantial portion of processing exports is intermediate inputs supplied to firms in other East Asian economies (Xing, 2012), so it is necessary to control the regional bias of value chains involving Chinese firms. In addition, we introduce the dummy variable Epot to identify import countries that are entrepots, i.e. countries through which Chinese exports are shipped to third countries. Entrepots here include Hong Kong, Macao and Luxembourg. $E X_{\$ t}$ is the nominal yuan-US dollar exchange rate. Exchange rate is a standard independent variable included in all models of exports. Exchange rates affect processing exports mainly through the channel of firms' points of entry and exit, not through conventional price mechanisms. The exit of firms specializing in processing exports gives rise to changes in export structure. Since the dependent variable is defined as the ratio of processing exports to total exports, if the coefficient of $E X_{\$ t}$ is significantly different from zero, exchange rates have a much stronger effect on processing exports than on ordinary exports.

We estimate model (4) separately for PAE, MAE and total processing exports, using data collected from various sources. Bilateral PAE, MAE, processing exports and total exports data were provided by China Customs. Wage and exchange rate data were retrieved from China Statistics Yearbooks. GDP per capita data for China's trading partners was downloaded from the World Development Indicators of the World Bank. The descriptive statistics indicate that the export share of PAE fell much faster than that of MAE. This suggests that wage shifts and the appreciation of the yuan affect PAE more than MAE. We 
estimate the model using both the ordinary least squared (OLS) model and the fixed effect model. Results of the unit root test suggest that the independent variable is stationary for all three cases, PAE, MAE and total processing exports. We used two different settings for proxy $W_{c t}$ : the average annual wage for all sectors and the average annual manufacturing salary

Table 1: Wages, Exchange Rates and Mixed Assembly Exports

\begin{tabular}{|c|c|c|c|c|}
\hline $\begin{array}{l}\text { Independent } \\
\text { Variables }\end{array}$ & $\mathrm{OL}$ & ates & & \\
\hline $\ln Y$ & $\begin{array}{l}0.272^{* * *} \\
(0.00785)\end{array}$ & $\begin{array}{l}0.272^{* * *} \\
(0.00785)\end{array}$ & $\begin{array}{c}0.706^{* * *} \\
(0.106)\end{array}$ & $\begin{array}{c}0.726 * * * \\
(0.107)\end{array}$ \\
\hline $\ln W$ & $\begin{array}{c}0.000550 \\
(0.0227)\end{array}$ & & $\begin{array}{c}-0.0739 * * * \\
(0.0253)\end{array}$ & \\
\hline InEX & $\begin{array}{c}0.427 * * * \\
(0.146) \\
\end{array}$ & $\begin{array}{c}0.411^{* * *} \\
(0.151)\end{array}$ & $\begin{array}{c}0.458^{* * *} \\
(0.121)\end{array}$ & $\begin{array}{c}0.422^{* * *} \\
(0.126) \\
\end{array}$ \\
\hline EAD & $\begin{array}{c}0.417 * * * \\
(0.0278) \\
\end{array}$ & $\begin{array}{c}0.417^{* * *} \\
(0.0279) \\
\end{array}$ & & \\
\hline Entrepot & $\begin{array}{c}0.153^{* * *} \\
(0.0550)\end{array}$ & $\begin{array}{c}0.153^{* * *} \\
(0.0551)\end{array}$ & & \\
\hline InMW & & $\begin{array}{r}-0.00405 \\
(0.0248)\end{array}$ & & $\begin{array}{c}-0.0897 * * * \\
(0.0277)\end{array}$ \\
\hline Constant & $\begin{array}{c}-4.900 * * * \\
(0.410)\end{array}$ & $\begin{array}{c}-4.844^{* * *} \\
(0.428)\end{array}$ & $\begin{array}{c}-8.098 * * * \\
(0.867)\end{array}$ & $\begin{array}{c}-8.119 * * * \\
(0.861) \\
\end{array}$ \\
\hline Observations & 2,401 & 2,401 & 2,401 & 2,401 \\
\hline R-squared & 0.352 & 0.352 & 0.625 & 0.626 \\
\hline
\end{tabular}

Source: the author's calculations

Table 1-3 summarizes the estimation results. The estimates of OLS for each category of processing exports are listed for comparison The following analysis is based on the results of the fixed effect model with manufacturing wages. Table 1 summarizes the estimates of MAE. The coefficient of income is 0.726 , statistically significant at $1 \%$, suggesting that the income level of China's trading partners is positively correlated with the intensity of MAE. The estimated coefficient suggests that a $1 \%$ increase in the income of the trading partners would result in a 2.1 percentage points increase in the share of MAE, indicating that MAE mainly target the markets of high-income countries. The estimated coefficient of exchange rates is 0.422 , also statistically significant at $1 \%$. Because exchange rate $E X$ is defined as the price of the US dollar in yuan, the 
positive coefficient implies that the depreciation of the yuan would give rise to an increase in the intensity of MAE. Specifically, a 1\% nominal depreciation of the yuan is expected to lift the share of MAE by 1.5 percentage points. Conversely, a $1 \%$ appreciation of the yuan would reduce the share of MAE by 1.5 percentage points. Given that the Chinese yuan has appreciated nominally against the US dollar by more than $35 \%$ since 2005 , the declining share of MAE in both China's aggregate and bilateral exports can be attributed in part to the cumulative appreciation of the yuan. The coefficient of wages is -0.0897 , statistically significant at $1 \%$. The negative coefficient is consistent with our hypothesis that wage increases have gradually eroded China's competitiveness in processing exports and triggered the exit of both domestic and foreign firms from the assembly business. The coefficient suggests that a $1 \%$ increase in manufacturing wages would reduce the share of MAE by 1.1 percentage points. Since 2000 the average wage in China has risen by more than $13 \%$ each year, which suggests that cumulative increase in wages is one of the major factors driving the change in the structure of China's exports and mitigating China's dependence on processing exports.

Table 2: Wages, Exchange Rates and Pure Assembly Exports

\begin{tabular}{|c|c|c|c|c|}
\hline $\begin{array}{l}\text { Independent } \\
\text { Variables }\end{array}$ & \multicolumn{2}{|c|}{ OLS Estimates } & \multicolumn{2}{|c|}{ Fixed Effect } \\
\hline $\ln Y$ & $\begin{array}{c}0.524 * * * \\
(0.0155)\end{array}$ & $\begin{array}{c}0.524^{* * *} \\
(0.0155)\end{array}$ & $\begin{array}{c}0.506^{* * *} \\
(0.193)\end{array}$ & $\begin{array}{c}0.541^{* * *} \\
(0.192)\end{array}$ \\
\hline $\ln W$ & $\begin{array}{c}-0.431 * * * \\
(0.0431) \\
\end{array}$ & & $\begin{array}{c}-0.403^{* * *} \\
(0.0498)\end{array}$ & \\
\hline $\ln E X$ & $\begin{array}{c}0.933^{* * *} \\
(0.287)\end{array}$ & $\begin{array}{c}0.782 * * * \\
(0.295)\end{array}$ & $\begin{array}{c}1.001^{* * *} \\
(0.233)\end{array}$ & $\begin{array}{c}0.856 * * * \\
(0.243)\end{array}$ \\
\hline EAD & $\begin{array}{l}1.582 * * * \\
(0.0576)\end{array}$ & $\begin{array}{l}1.582 * * * \\
(0.0575)\end{array}$ & & \\
\hline Entrepot & $\begin{array}{c}-0.436 * * * \\
(0.112) \\
\end{array}$ & $\begin{array}{c}-0.436^{* * *} \\
(0.112) \\
\end{array}$ & & \\
\hline InMW & & $\begin{array}{c}-0.482 * * * \\
(0.0473)\end{array}$ & & $\begin{array}{c}-0.459 * * * \\
(0.0544)\end{array}$ \\
\hline Constant & $\begin{array}{c}-7.805^{* * *} \\
(0.797) \\
\end{array}$ & $\begin{array}{c}-7.284^{* * *} \\
(0.831) \\
\end{array}$ & $\begin{array}{c}-7.841 * * * \\
(1.470)\end{array}$ & $\begin{array}{c}-7.594 * * * \\
(1.448)\end{array}$ \\
\hline Observations & 2,401 & 2,401 & 2,401 & 2,401 \\
\hline R-squared & 0.430 & 0.431 & 0.717 & 0.718 \\
\hline
\end{tabular}

Source: the author's calculations 
Table 2 reports the results of estimation for PAE, which are consistent with those for MAE. Specifically, all estimated PAE coefficients have the same signs and the same level of statistical significance as those of MAE, though the numerical values differ and the numerical differences are not trivial. The estimated coefficients of income, exchange rates and wages are $0.541,0.856$ and -0.459 respectively. We can say unequivocally that the impacts of exchange rates and wages on PAE are much higher than on MAE. To illustrate the differences, we calculate the expected impact of a $1 \%$ increase in each of income, exchange rate and wages on MAE and PAE. The results are shown in Figure 5.

Figure 5. The Impacts of a $1 \%$ increase in wages, exchange rate and income

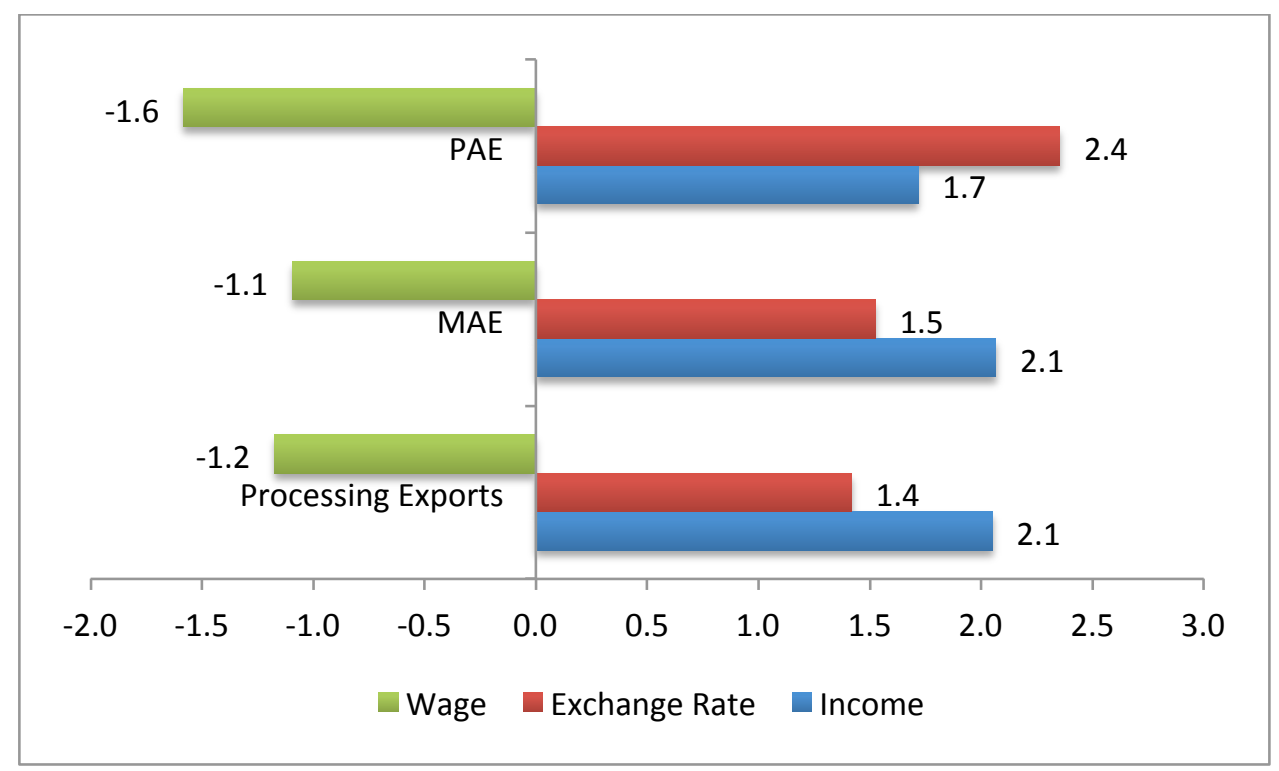

Source: the author's calculations

While the effect of income on MAE is stronger than that on PAE, exchange rates and wages have a stronger influence on PAE. Specifically, a 1\% increase in wages would be expected to result in a 1.6 percentage point decrease in the export share of PAE, 0.5 percentage points greater than for MAE; and a $1 \%$ nominal appreciation of the yuan against the US dollar would lower the share of PAE by 2.4 percentage points, 0.3 percentage points more than for MAE. These differences indicate that PAE is affected more strongly by wage increases and currency appreciation than MAE. Foreign suppliers provide all parts and components for the manufacture of PAE. Assembly fees, 
generally denominated in US dollars, are the only source of profit for PAE firms. Wages are the primary determinant of the profit margins. Aside from productivity improvement, PAE firms have essentially no other means of absorbing the costs of wage increases and currency appreciation. On the other hand, firms engaging in MAE can absorb cost increases, either by lowering the cost of internally manufactured parts or by passing those increases on the domestic suppliers of parts and components. Therefore, faced with the same level of wage increase or currency appreciation, PAE firms are more likely to exit the assembly business than MAE firms. This explains why wages and exchange rates have a stronger effect on PAE than on MAE.

Table 3 shows estimates of total processing exports from China. Those results are consistent with the estimates for PAE and MAE. Total processing exports comprise PAE and MAE, so it is not surprising that the statistical inferences regarding total processing exports are similar to those for PAE and MAE. The estimate of total processing exports lends further support for the conclusions derived from the estimates of PAE and MAE.

Table 3: Wages, Exchange Rates and Processing Exports

\begin{tabular}{|c|c|c|c|c|}
\hline $\begin{array}{l}\text { Independent } \\
\text { Variables }\end{array}$ & \multicolumn{2}{|c|}{ OLS Estimates } & \multicolumn{2}{|c|}{ Fixed Effect } \\
\hline $\ln Y$ & $\begin{array}{l}0.299 * * * \\
(0.00777)\end{array}$ & $\begin{array}{l}0.299 * * * \\
(0.00777) \\
\end{array}$ & $\begin{array}{c}0.696 * * * \\
(0.0994) \\
\end{array}$ & $\begin{array}{c}0.718^{* * *} \\
(0.0997) \\
\end{array}$ \\
\hline $\ln W$ & $\begin{array}{c}-0.0690 * * * \\
(0.0221)\end{array}$ & & $\begin{array}{c}-0.137^{* * *} \\
(0.0239)\end{array}$ & \\
\hline InEX & $\begin{array}{c}0.372^{* *} \\
(0.146)\end{array}$ & $\begin{array}{c}0.336^{* *} \\
(0.151)\end{array}$ & $\begin{array}{c}0.405^{* * *} \\
(0.114)\end{array}$ & $\begin{array}{c}0.349 * * * \\
(0.118)\end{array}$ \\
\hline EAD & $\begin{array}{c}0.539 * * * \\
(0.0274) \\
\end{array}$ & $\begin{array}{c}0.539 * * * \\
(0.0274) \\
\end{array}$ & & \\
\hline Entrepot & $\begin{array}{l}0.123^{* *} \\
(0.0499) \\
\end{array}$ & $\begin{array}{l}0.123^{* *} \\
(0.0499)\end{array}$ & & \\
\hline InMW & & $\begin{array}{c}-0.0809 * * * \\
(0.0243)\end{array}$ & & $\begin{array}{c}-0.159 * * * \\
(0.0262)\end{array}$ \\
\hline Constant & $\begin{array}{c}-4.442^{* * *} \\
(0.406) \\
\end{array}$ & $\begin{array}{c}-4.313^{* * *} \\
(0.425) \\
\end{array}$ & $\begin{array}{c}-7.373^{* * *} \\
(0.800) \\
\end{array}$ & $\begin{array}{c}-7.335^{* * *} \\
(0.793) \\
\end{array}$ \\
\hline Observations & 2,401 & 2,401 & 2,401 & 2,401 \\
\hline R-squared & 0.434 & 0.434 & 0.722 & 0.722 \\
\hline
\end{tabular}

Source: the author's calculations 


\section{Concluding Remarks}

The fall of China's export growth is not only the result of sluggish external demand, but also of substantial shrinkage of processing export capacity. Persistent wage increases and cumulative appreciation of the yuan are the two major factors compelling both domestic and foreign firms to exit the assembly business. This exit in turn undercuts China's export capacity and reduces its growth momentum. The conventional literature identifies price mechanisms as the main channel by which wages and exchange rates affect exports. It is argued here that in the case of processing exports (a subset of GVC activity), price mechanisms are not a major channel through which wages and exchange rates can exert an impact, because the manufacturers of assembled exports have little pricing power. Rather, wages and exchange rates affect firms' entry into and exit from the assembly business. Instead of estimating exchange rate elasticity, this study examines the extent to which wage and exchange rates have impacted China's export structure, defined as a composite of OE, PAE and MAE.

The empirical analysis presented here demonstrates that wage increases and the appreciation of the yuan have significantly reduced the intensity of both PAE and MAE in China's bilateral trade, thus undermining the growth of aggregate exports. The data analyzed were derived from panel data covering China's bilateral PAE and MAE with its major trading partners during the period 1991-2013. The analysis affords a supply side explanation for China's dramatic fall in export growth to $-2.8 \%$ from $20 \%$ five years earlier. Processing exports, which accounted for more than $55 \%$ of China's total exports during the high growth period, fell to $39 \%$ in 2013 . Our empirical results suggest that the contraction of processing exports is primarily the result of wage increases and the cumulative appreciation of the yuan, and that declining processing export production capacity played a far more important role than weakened external demand in undermining the growth of exports. 


\section{References}

Aziz, J. and Li, X. (2007). China's Changing Trade Elasticities. International Monetary Fund Working Paper 07/266. Washington, DC: International Monetary Fund.

Cheung, Y., Chinn, M., and Fujii, E. (2009). China's Current Account and Exchange Rate. National Bureau of Economic Research Working Paper 14673. Cambridge, MA: National Bureau of Economic Research.

Garcia-Herrero, A. and Koivu, T. (2009). China's Exchange Rate Policy and Asian Trade. Bank for International Settlements Working Paper No. 282. Basel, Switzerland: Bank for International Settlements.

JETRO. (2015). The $25^{\text {th }}$ Survey of Investment Related Costs in Asia and Oceania.

JETRO. (2014). Survey of Japanese-Affiliated Firms in Asia and Oceania.

Half of Panasonics Air Purifiers will be produced in Japan (2015 Aug 19). Kyodo News.

Japanese companies head for exits as Chinese economy loses steam (2015 June 2). Nikkei.

Sun, Y. and Grimes, S. (2015). China's Increasing Participation in ICTs Global Value Chain: a Firm Level Analysis. Telecommunication Policy, forthcoming.

Thorbecke, W. and Smith, G. (2010). How Would an Appreciation of the Renminbi and Other East Asian Currencies Affect China's Exports? Review of International Economics, Vol. 18(1), 95-108.

Xing, Y. (2016). Global Value Chains and China's Exports to High-Income Countries. International Economic Journal, forthcoming.

Xing, Y. (2014). China's High-Tech Exports: the Myth and Reality. Asian Economic Papers, Vol. 33(1), 109-123.

Xing, Y. (2012). Processing Trade, Exchange Rates and China's Bilateral Trade Balances. Journal of Asian Economics, Vol. 23(5), 540-547. 